\title{
The Commercialisation of Rice Farming in Cambodia
}

\section{Rob Cramb, Chea Sareth, and Theng Vuthy}

In this and the next five chapters the focus is on the commercialisation of rice farming in the Central Plain of Cambodia. Particularly since 2010, rice has come to be seen as more than merely a subsistence crop or a staple for domestic consumption but as "white gold"-a commodity with major commercial, including export potential (RGC 2010). To explore this trajectory, field studies were undertaken in Takeo Province and the lowland part of the adjacent province of Kampong Speu in the southern part of the Central Plain, embracing rainfed and irrigated lowlands (Fig. 11.1). These studies examined the economics of rice production, marketing, and trade

R. Cramb $(\bowtie)$

School of Agriculture and Food Sciences, University of Queensland, St Lucia, QLD, Australia

e-mail: r.cramb@uq.edu.au

C. Sareth

Cambodian Agricultural Research and Development Institute, Phnom Penh, Cambodia

e-mail: sareth.chea@uqconnect.edu.au

T. Vuthy

Office of Food Security and Environment, USAID, Phnom Penh, Cambodia e-mail: vtheng@usaid.gov

(C) The Author(s) 2020

R. Cramb (ed.), White Gold: The Commercialisation of Rice

Farming in the Lower Mekong Basin, https://doi.org/10.1007/978-981-15-0998-8_11 


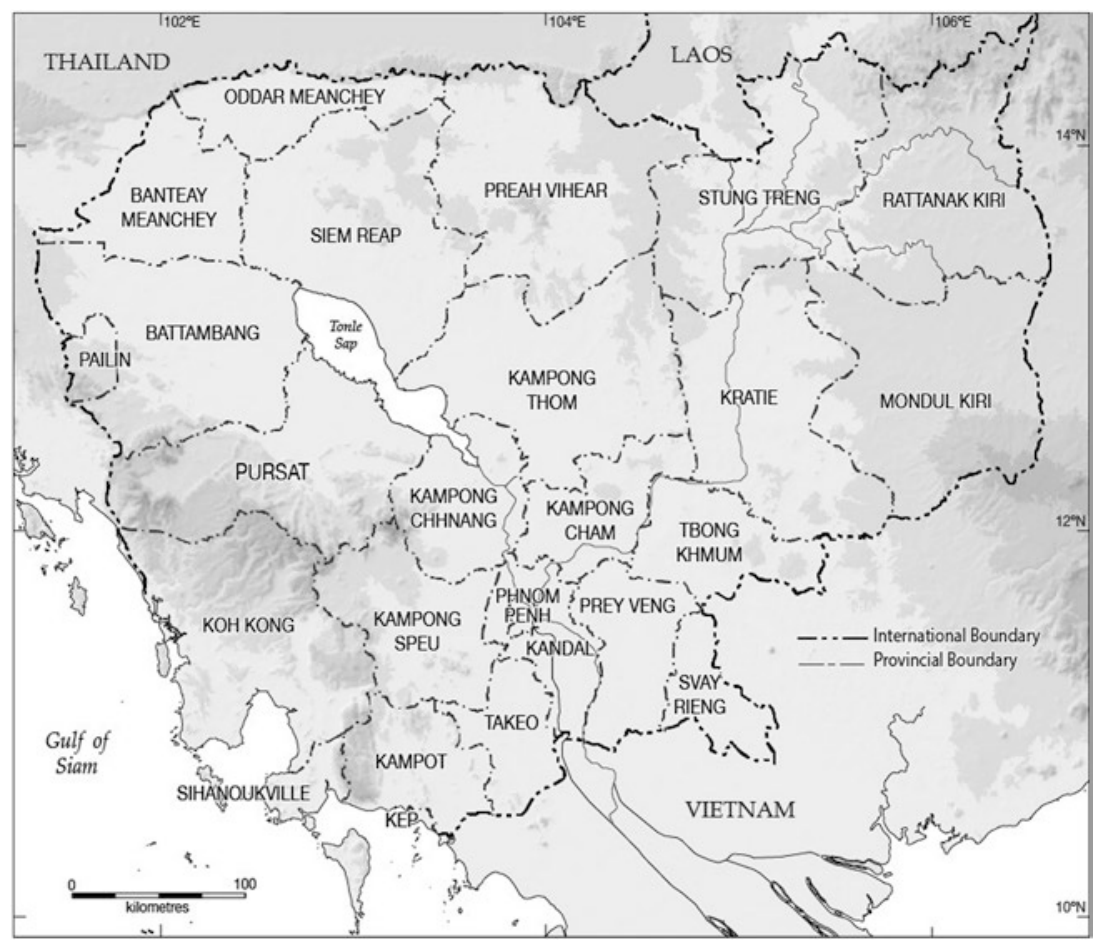

Fig. 11.1 Cambodia, showing provinces and terrain. (Source: CartoGIS, Australian National University)

in Takeo (Chap. 12), the role of the key inputs of water (Chap. 13) and fertilisers (Chap. 14) in supporting commercial rice production, the provision of credit to rice farmers by micro-finance institutions (Chap. 15), and the potential for contract farming to alleviate some of the key constraints to commercialisation (Chap. 16). This chapter sets the scene for the in-depth studies in the chapters that follow by (1) describing the rice-growing environment in Cambodia as a whole, (2) outlining the history of rice production in Cambodia, (3) examining the role of the rice sector in the rapid agricultural and economic growth in Cambodia since 1993, (4) highlighting the changes at the farm level that have underpinned this agricultural growth, and (5) providing a profile of Takeo Province within this larger context. 


\section{The Rice-Growing Environment}

Cambodia encompasses a distinct physiographic region within the Mekong catchment referred to as the Tonle Sap Basin, beginning in southern Laos just above Pakse and spreading out into an extensive plain in central Cambodia, bordered on the east, north, and south-west by mountain ranges (MRC 2017). The dominant tributaries entering on the left bank are the Se Kong, Se San, and Sre Pok Rivers in Stung Treng and Rattanak Kiri Provinces in the north-east. The Tonle Sap River flows into the Mekong on its right bank at Phnom Penh, but famously reverses flow in the wet season to accommodate the floodwaters from upstream, expanding the size of the vast Tonle Sap Lake six-fold to about $25,000 \mathrm{~km}^{2}$. Below Phnom Penh the Mekong branches into the Bassac River, its major distributary, thus forming the beginning of the Mekong Delta. Of Cambodia's total land area of $181,035 \mathrm{~km}^{2}, 86 \%$ lies within the Mekong Basin, forming $20 \%$ of the entire catchment. Only the coastal region to the south-west of the Cardamom and Elephant Ranges lies outside the Basin, draining into the Gulf of Siam.

Rainfall in the lowlands varies from 1250 to $1750 \mathrm{~mm}$ annually, with a distinct but erratic wet season (WS) from mid-April to mid-November, followed by a five-month dry season (DS) in which rice cannot be grown without some form of irrigation (Nesbitt 1997a). Hence most of the rice lands support only a single rainfed WS crop, accounting for about $87 \%$ of the annual cultivated area (MAFF 2013). In some areas around the Tonle Sap Lake and close to the Mekong floodplain which are inundated in the WS, deep-water or floating rice is grown. Some of the floodplain areas are only used for DS rice, which is planted as the floodwaters recede. Upland rice is of limited importance.

Rice soils in the lowlands are of two broad types (White et al. 1997). Those of the old alluvial and colluvial plains account for $67 \%$ of the lowland rice area and are generally light-textured soils of low fertility used for rainfed WS rice. Soils in the active floodplains around the Tonle Sap Lake and the Mekong and Bassac Rivers account for $30 \%$ of the rice area. These soils are heavy-textured and fertile, being formed from fresh alluvium deposited by annual floodwaters. They are submerged for three to five months of the year and are commonly used for deep-water rice and recessional/irrigated DS rice.

For millennia, the Cambodian population has been dependent on rice cultivation, concentrated around the Tonle Sap and the south-eastern 
lowlands. Rainfed lowland rice remains the mainstay of the rural economy. Cambodia's population was 16 million in 2017, of whom almost $80 \%$ resided in rural areas, most engaged in rice farming and other livelihood activities. About $91 \%$ of the population is of the Khmer ethnic group. Minorities include Vietnamese (3\%), concentrated in the Delta to the south-east, Chinese (1\%), and Cham, Lao, Tai, and other groups (5\%). The population growth rate in 2017 was $1.6 \%$, down from a peak of $3.9 \%$ in $1984 .^{1}$ The population density averaged 90 persons $/ \mathrm{km}^{2}$ but varied from $100-400$ persons $/ \mathrm{km}^{2}$ in the Central Plain to $4-50$ persons $/ \mathrm{km}^{2}$ in the uplands (NIS 2008).

\section{History of Rice Production}

Rice has been cultivated by Khmer farm households in these lowlands of Cambodia for perhaps 3000 years and probably longer in the uplands (Helmers 1997; Higham 2014). The more intensive lowland rice techniques developed in southern China-involving the use of the plough to prepare bunded rice fields into which seedlings are transplanted from a nursery-were introduced about 1500 years ago. The powerful kingdom of Angkor which dominated the region from the ninth to the fourteenth centuries was based on the appropriation of rice surpluses and the mass mobilisation of rural labour through corvées and slavery. The capital of Angkor located near Siem Reap to the north of the Tonle Sap Lake was surrounded by rice paddies irrigated from large reservoirs through a system of canals, permitting multiple cropping (Higham 2014: 400-403). With the decline of Angkor, the centre of population moved to the southeastern part of present-day Cambodia, which is still the most densely populated part of the country. Rice farming in this period was probably sufficient for the needs of rural households, though it was still faced with threats from an unpredictable environment, state-imposed taxes, labour corvées, and periodic conflicts. Nevertheless, over the centuries, farmers had adapted rice-growing to the different ecosystems and selected suitable varieties for local conditions; about 2000 traditional rice varieties have been identified as unique to Cambodia (Helmers 1997).

Under the French colonial regime, little was done to improve smallholder rice production; hence yields remained at a little over $1 \mathrm{t} / \mathrm{ha}$. The growth of production was almost entirely due to the expansion of cultivated area. From 1900 to 1950, the area cultivated increased, in line with population growth, from about 400,000 ha to $1,660,000$ ha, and total 
production increased from $560,000 \mathrm{t}$ to $1,580,000 \mathrm{t}$, but the average yield declined from $1.4 \mathrm{t} / \mathrm{ha}$ to $1.0 \mathrm{t} / \mathrm{ha}$ (Slocomb 2010: 59). From 1900 the French administration pursued a policy of promoting agricultural exports, especially of rice and cattle, to supply French agro-processing and export businesses in Saigon (Helmers 1997). French settlers were given more than 16,000 ha of land concessions to establish large rice estates on fertile soils in Battambang Province using hired labour. These estates were supported with infrastructure including irrigation works, research stations (focusing on varieties, fertilisers, and mechanisation), and a railway line to Phnom Penh. In the pre-war decades, rice exports ranged from 50,000 to $200,000 \mathrm{t}$ of paddy per year, of which around 30,000 t came from the Battambang plantations and the rest from smallholders. By 1940, Cambodia was the world's third largest rice-exporting country (Helmers 1997). Smallholders did reasonably well out of these sales when prices were high, such as in the 1920s, but scaled back cultivation to subsistence levels and sought relief from the rice tax when prices fell, as in the 1930s.

Under Prince Sihanouk's Sangkum government (1953-1970), there was investment in irrigation infrastructure in some provinces and six rice research stations were established for varietal trials and seed production. The government also took control of the French rice plantations in Battambang. By 1965, paddy production had grown to 2.75 million $t$ and exports to $500,000 \mathrm{t}$, almost entirely due to further expansion in cultivated area; yields remained around $1.1 \mathrm{t} / \mathrm{ha}$ (Helmers 1997). A state corporation was established in 1962 with a monopoly over production inputs and rice exports. By the mid-1960s, the corporation sought to forcibly collect rice at low official prices, prompting the growth of black-market trade to Vietnam and armed rebellions in Battambang and elsewhere (Kiernan and Boua 1981).

A favourable season in 1969 meant that, in early 1970, the rice crop was a record 3.8 million t. However, as the Indochina War escalated, including American carpet bombing in the east of the country, rice production was devastated. Under Lon Nol's Khmer Republic (19701975), total output fell by 84\% (Helmers 1997; Slocomb 2010: 147149). Exports were suspended in 1971 in an attempt to shore up domestic stocks. The Democratic Kampuchea (Khmer Rouge) regime that controlled Cambodia from 1975 to 1979 focused on developing rice production (Helmers 1997; Slocomb 2010: 205-207), not just for subsistence but to provide the surplus to fund its revolutionary programme for economic independence (or "Super Great Leap Forward"). The 
regime brutally forced people to work in the paddy fields and construct irrigation systems throughout Cambodia as part of its ambitious plan to achieve two or three crops a year and raise yields to $3 \mathrm{t} /$ ha Himmel 2007). However, most of the irrigation schemes failed and the forced collectivisation of labour left the country's agriculture in disarray. Rice was requisitioned to supply the army and to export in exchange for arms, while locals starved. When Vietnamese forces took over in 1979, they found that the countryside was devastated and famine was widespread.

The Vietnamese-installed People's Republic of Kampuchea (PRK) (1979-1989) focused on rehabilitating rice farming, but with very limited resources (Helmers 1997; Slocomb 2010: 207-209). Farming was again organised on socialist lines, with all land collectivised and groups of 20-25 households constituted as the basic unit of production, though in practice it was common for individual households to manage their own plots within the village communal land and for the groups to merely share animals and equipment and to exchange labour. Vietnamese advisers introduced some International Rice Research Institute (IRRI) varieties such as IR36 and IR42 but there was no rice research service to test or promote these and other modern inputs. The Cambodia-IRRI-Australia Project (CIAP) was established in 1987 and began to build the country's rice research capacity, but the impact was not seen until the 1990s.

Slocomb (2010: 209) reports that, from 1980 to 1989, the area cultivated increased by only $31 \%$ from $1,441,000$ ha to $1,890,000$ ha, short of the PRK's target of 2.5 million ha, and total production increased by $54 \%$ from 1,670,000 t to 2,570,000 t, below the target of 3 million t. Average yields increased only slightly from 1.2 to $1.4 \mathrm{t} / \mathrm{ha}$. Nevertheless, by the end of the decade, Cambodia was almost self-sufficient in rice. In 1989, the PRK was renamed the State of Cambodia and crucial reforms were introduced (Helmers 1997; Slocomb 2010: 225). Private land tenure was established, with the communal lands broken up and allocated to individual households based on the number of household members, and the market economy was legitimised, in recognition of its de facto reassertion in the preceding decade.

After the United Nations (UN)-supervised elections in 1993, the Royal Government of Cambodia (RGC) was installed, paving the way for increased foreign investment and aid directed to agricultural and rural development. At this point, farmers in the lowlands were still largely dependent on conventional farming practices, low-yielding traditional varieties, very low rates of inorganic fertilisers, almost no use of 
agrochemical inputs, and little mechanisation of land preparation or harvesting. They were subject to various pressures, including the seasonality and variability of rainfall, lack of irrigation, poor soil fertility, weed and pest problems, few farm resources, and limited access to inputs, credit, and markets. The average yield from rainfed lowland rice was only $1.5 \mathrm{t} / \mathrm{ha}$, one of the lowest in Asia (Nesbitt 1997b; Javier 1997). Hence the majority of households were producing rice at subsistence levels. In addition, opportunities for productive employment of land and labour in the dry season were limited. Meanwhile population growth in the decade to 1993 had surged to between 2.9 and $3.9 \%$.

As mentioned earlier, agricultural research had resumed in the late 1980s under CIAP and this began to have an impact in the 1990s. The primary objective was to improve rice production to alleviate the country's chronic rice shortage. By 2006, 37 improved varieties had been developed and released, mainly for the rainfed lowlands, with a potential yield range of 2.5-4.5 t/ha (Sakhan et al. 2007). The programme also covered rice agronomy, pest management, soil classification, and mechanisation (Nesbitt 1997b). This research effort has had a significant impact on rice yields and production in Cambodia, providing the basis for the expansion of output and exports in recent decades.

\section{Agricultural and Economic Growth Since 1993}

After the war-time devastation of the 1970s and 1980s, the Cambodian economy has experienced more than two decades of rapid growth, averaging 7.6\% over the period 1994-2015 (World Bank 2017). Gross national income (GNI) per capita reached USD 1070 in 2015, giving Cambodia the status of a lower-middle-income country. This growth has been associated with a marked reduction in poverty, from $48 \%$ in 2007 to $14 \%$ in 2014 , though most families who escaped poverty remain "nearpoor" and economic inequality is increasing. With the growth of the industry and service sectors (particularly garment manufacture, construction, and tourism), agriculture's share of the economy has declined. Agriculture Value Added as a proportion of gross domestic product (GDP) fell from $50 \%$ in 1995 to $28 \%$ in 2015 , though agricultural workers still comprised $51 \%$ of the labour force in 2012 .

While industry and services have grown faster than agriculture, the agricultural sector has also grown at a rapid rate. Gross Agricultural Production grew at 8.7\% during 2004-2012 and Agricultural Value Added 
at 5.3\% (World Bank 2015). This rapid growth was driven by crop production, mainly the rice sector, the output of which has grown at $5 \%$ from 1990 to 2017 (Fig. 11.2). About two-thirds of the reduction in poverty during this period was attributable to agricultural growth, where higher rice prices stimulated increased production and farm incomes as well as pushing up farm wages. According to a review of the agricultural sector by the World Bank (2015), Cambodian agriculture has benefited from a market-oriented policy, including (1) an open trade policy, enabling farmers to benefit from improved access to the European Union (EU) market as well as cross-border trade with Thailand and Vietnam; (2) wider availability of machinery services such as threshers and combine harvesters; (3) better access to rural finance, especially micro-finance; and (4) investment in rice milling.

The growth in rice production was due partly to an expansion of cultivated area (at a rate of $1.7 \%$ during 1990-2017) but more so to an increase in yields (at a rate of $3.5 \%$ in the same period). Moreover, the area expansion has levelled off while there is still potential for further yield growth (Fig. 11.2). The national rice yield now averages $3.5 \mathrm{t} / \mathrm{ha}$, compared with

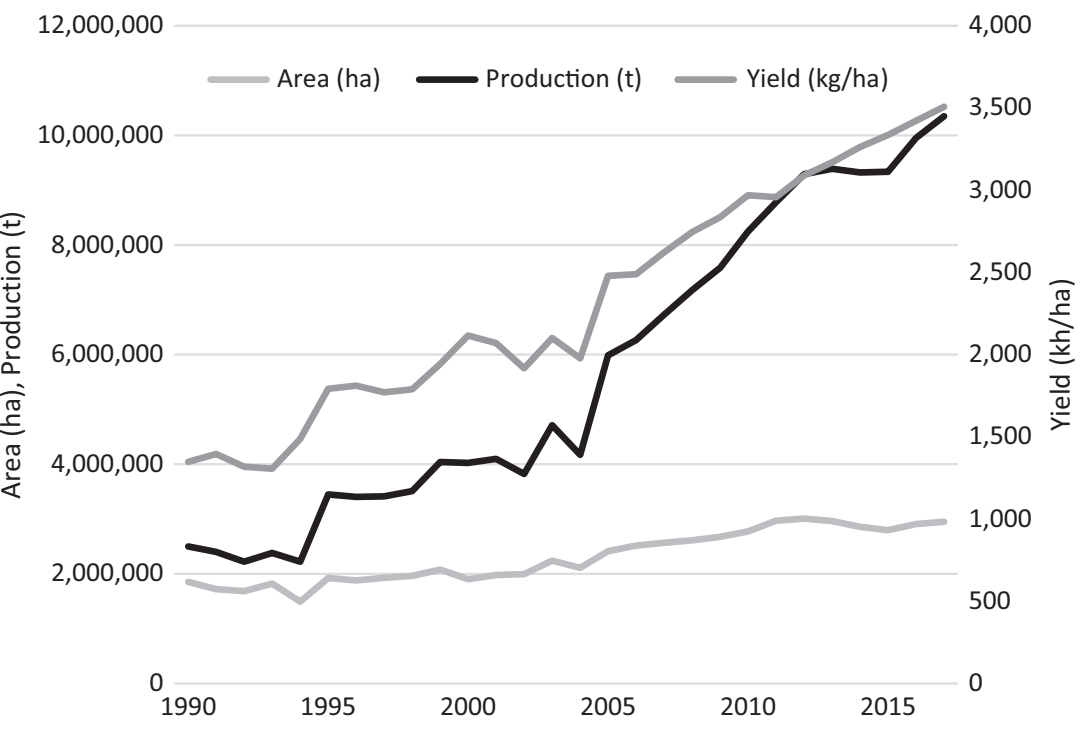

Fig. 11.2 Area, yield, and output of rice in Cambodia, 1990-2017. (Source: FAOSTAT) 
Table 11.1 Rice production data for Cambodia and Takeo Province, 2017-2018

\begin{tabular}{lllr}
\hline Variable & Cambodia & Takeo & Takeo \% \\
\hline Total area (ha) & $3,335,929$ & 302,546 & 9.1 \\
Wet season area (ha) & $2,739,446$ & 199,643 & 7.3 \\
Dry season area (ha) & 596,483 & 102,903 & 17.3 \\
Overall yield (t/ha) & 3.35 & 3.90 & 116.4 \\
Wet season yield (t/ha) & 3.09 & 3.39 & 109.7 \\
Dry season yield (t/ha) & 4.50 & 4.90 & 108.9 \\
Total production (t) & $10,891,735$ & $1,179,936$ & 10.8 \\
Wet season production (t) & $8,212,893$ & 676,051 & 8.2 \\
Dry season production $(\mathrm{t})$ & $2,678,842$ & 503,885 & 18.8 \\
\hline
\end{tabular}

Source: Ministry of Agriculture, Forestry and Fisheries, Cambodia

1.1 t/ ha in the 1960s and 1.5 t/ha in the 1990s (MAFF 2013; Helmers 1997; Nesbitt 1997b). The yield increase was mainly due to the adoption of improved varieties and increased use of fertiliser; only $8-9 \%$ of arable land is irrigated in the DS and the potential for expanding surface irrigation infrastructure is limited (Johnston et al. 2013). Nevertheless, the DS rice area increased from $13 \%$ of the total rice area in 2008 to $18 \%$ in $2017-$ 2018 (World Bank 2015; Table 11.1). The more profitable Cambodian aromatic rice varieties, mainly grown in the western provinces such as Battambang, now account for $10 \%$ of the annual cultivated area and $30 \%$ of total production (World Bank 2015).

The growth in production has generated a rice surplus above estimated domestic requirements (World Bank 2015). The notional surplus increased from 1.44 million $t$ of milled rice in 2008 to 2.38 million $t$ in 2013 . With increasing liberalisation of trade and explicit government encouragementespecially with the 2010 Policy Paper on the Promotion of Paddy Production and Rice Export, in which rice was designated as "White Gold"-the export of rice has increased sharply (ADB 2014). In 2013, formal exports of rice were $378,850 \mathrm{t}$, exported to over 50 countries, $91 \%$ of which were in the EU or Asia; half of these official exports were of high-quality fragrant rice. This was well below the target enunciated in the 2010 Policy Paper of 1 million $t$ of milled rice exports by $2015 .^{2}$ However, in 2013, informal cross-border trade of rice and paddy (unmilled rice) to Vietnam and Thailand was estimated to be 1.5 million $\mathrm{t}$ (in milled rice equivalent). ${ }^{3}$ Thus total exports of rice and paddy increased nearly 20 -fold from 2008 
to 2013 , from just over 100,000 t to 1.9 million $\mathrm{t}$ (in milled rice equivalent). ${ }^{4}$ Though drying and milling capacity remains a constraint and exports are still mainly in the form of paddy, capacity has increased from $20 \mathrm{t} / \mathrm{hr}$ in 2009 , when there were only two large rice milling companies, to over $700 \mathrm{t} / \mathrm{hr}$ in $2013 .{ }^{5}$ In 2018 official data indicated that milled rice exports had risen further to $626,225 \mathrm{t}$. There was no corresponding figure for official and unofficial paddy exports, but the evidence is that these continue to exceed the exports of milled rice by a substantial margin.

\section{Changes in Rice Production at the Farm Level}

Realising the benefits of this growth at the farm household level depends on access to land, labour, water, finance, and markets. However, many rice-growing households, especially in the south-eastern lowlands, have farms of less than one hectare. For Cambodia as a whole, the average size of rice farms increased from 1.9 ha in 2008 to 2.1 ha in 2012 (World Bank 2015), reflecting out-migration from the densely populated south-east and in-migration and area expansion in the north and north-west. However, this disguises an increase in inequality, with the average size of small farms decreasing during 2008-2012 (from 1.0 ha to 0.9 ha) and the average size of medium and large farms increasing (from 1.6 ha to 2.4 ha, and from 3.6 ha to 7.0 ha, respectively).

At the same time, the unit profitability of rice farming has increased. Gross margins (GMs) for WS rice were estimated to be about USD 250/ ha and USD 5/day in 2013, and for DS rice, USD 300/ha and USD 10/ day (World Bank 2015). ${ }^{6}$ However, for small farms using modern technology, the GM in 2013 was USD 522/ha in the WS and USD 276/ ha in the DS (comparable to the GMs found in the Takeo field studies reported in the next five chapters). During 2005-2013, the GM per ha for WS rice grew in real terms at $2.4 \%$ due to the increase in yield and price. In the same period, the GM per ha for DS rice grew at $2.1 \%$. The growth in profitability as well as the growth in population has increased the demand for land, as reflected in rising prices - the purchase price for rainfed lowland plots increased by 271\% from 2005 to 2013 and for irrigated land by $620 \%$ (World Bank 2015).

Rice farming has also been undergoing rapid mechanisation, following the trend in Thailand and Vietnam, with significant implications for labour requirements (World Bank 2015). Mechanisation initially took the form of power tillers (two-wheeled tractors) for land preparation and small, 
moveable pumps for irrigation (whether from rivers, canals, receding floodwaters, farm ponds, or tube wells). These were attractive because they were affordable, multifunctional, and saved on labour, time, and costs. Contracted services of reapers and threshers were also widely taken up but are being overtaken by combine harvesters, the number of which is rapidly increasing. However, methods to save on planting labour such as drum seeders and rice planters have not been widely adopted. As a consequence of this mechanisation process, the labour used in WS rice production decreased from 85 days/ha in 2005 to 48 days/ha in 2013, and even more in DS rice production, from 90 days/ha to 28 days/ha (World Bank 2015: 67). There is potential for these labour requirements to be reduced further if the trend in neighbouring countries is a guide.

As noted earlier, access to irrigation schemes has been limited and there are few suitable sites for further expansion of surface irrigation infrastructure. However, in recent decades there has been an increase in the use of groundwater for irrigation, especially in the south-eastern lowlands (Johnston et al. 2013). While groundwater has been used for domestic purposes for centuries, the availability of small, portable pumps has encouraged many farmers to sink tube wells in their rice fields and use this source for supplementary irrigation of WS or DS (recessional) rice, or for alternative, less-water-demanding DS crops. The sustainability of this use of groundwater is still a matter for research, with some evidence of long-term decline in Prey Veng and Svay Rieng Provinces, though in Kandal and Takeo, closer to the main channel of the Mekong and Bassac Rivers, it seems that aquifers are readily recharged during each wet season. As discussed in Chap. 12, access to this form of on-farm irrigation can have a significant impact on the productivity of rice-based cropping systems.

Another trend affecting the capacity of small-scale rice farmers to increase production and incomes is the availability of credit. Before the 1990s, farmers only had access to short-term, high-interest loans from local moneylenders. From 1993 there was a proliferation of non-government organisations (NGOs) involved in rural development, some of which offered microfinance. One of these has grown into the Association of Cambodian Local Economic Development Agencies (ACLEDA) Bank, Cambodia's largest commercial bank with branches in Myanmar and Laos. From 2000 onwards, government reforms enabled many of these NGOs to become specialised micro-finance institutions (MFIs), providing loans at commercial interest rates for use as working capital (to pay for seed, fertiliser, hired labour, and other inputs) and to purchase durable capital items such as pumps and two- 
wheeled tractors (and also land). By 2011 there were 29 MFIs and the ACLEDA Bank providing financial services in 24 provinces, covering almost 60,000 villages and 1.1 million borrowers with outstanding loans of USD 573 million. The number of borrowers has increased three-fold between 2005 and 2011 and the value of loans by a factor of 11 (Chap. 15). The average value of outstanding loans was USD 515 per borrower.

Apart from rice farming, a significant proportion of farm households throughout Cambodia now also depend on non-farm work opportunities for their livelihoods. The recent rapid development of construction, light industry, and the services sector in urban centres, especially in and around Phnom Penh, has provided many job opportunities. Young household members frequently migrate to urban areas to seek non-farm employment to help support their families in the villages. However, these young wage earners have few skills and little future earning potential, while their absence from the villages can severely constrain the farm labour force. Another source of non-farm employment is the provision of contract services in rural areas by households with the resources to purchase large machinery, particularly combine harvesters.

\section{The STUdy AreA}

The location for the specific field studies reported in the next five chapters was Takeo Province and the adjacent lowland portion of Kampong Speu Province in the southern part of the Central Plain (Fig. 11.1). ${ }^{7}$ Most of the study area was characterised by the sandy, infertile soils of the old alluvial and colluvial plains, suited to WS rice, but in the south-east corner the richer, heavier soils of the Bassac floodplain predominated, providing the opportunity for DS rice. The annual rainfall ranges from 1000 to $1500 \mathrm{~mm}$, lower than the national total of 1500-2000 mm. Mean monthly rainfall records for Takeo and Kampong Speu Provinces for the 31-year period from 1982 to 2012 show that the lowest monthly rainfall occurred from December to March $(5-35 \mathrm{~mm} /$ month) and the highest in September and October (195-230 mm/month), although there was considerable variation in WS rainfall from year to year. For example, October rainfall varied from 0 to $500 \mathrm{~mm}$. Only July, August, and September avoided a complete drought over the three decades, with a minimum monthly rainfall of between 35 and $85 \mathrm{~mm}$.

Takeo Province covers an area of $3563 \mathrm{~km}^{2}$ and in 2010 was divided into 10 districts, 100 communes, and 1117 villages, with 199,373 
registered households (NCDD 2010). The town of Takeo, at the centre of the province, is located about $80 \mathrm{~km}$ south of the capital (Fig. 11.1). The province's location between Phnom Penh and the Mekong Delta has been favourable for accessing new agricultural technologies and markets for farm inputs and outputs, particularly with the improvement of transport infrastructure. National Highway 2 passes through the centre of the province, extending to the Vietnam border in Kiri Vong District. National Highway 3 passes through the north-west districts on the way to Kampot Province. This infrastructure has also favoured periodic migration to take up non-farm employment in Phnom Penh.

The study area has for centuries been an important site for the concentration of rural population based on rainfed lowland rice, perhaps dating back to the ancient polity of Funan around 2000 years ago. In the 1950s, the population density was already high, between 150 and 200 persons/ $\mathrm{km}^{2}$, with some districts nearing 500 persons $/ \mathrm{km}^{2}$; hence holdings of paddy land at that time were smaller than 2 ha, while grain yields from the single WS rice crop were low, averaging less than $1 \mathrm{t} / \mathrm{ha}$ (Delvert 1961). Apart from growing rice, farm households traditionally produced palm sugar, wove silk fabrics, and made bamboo baskets to support their livelihoods.

The total population of Takeo Province at the 2008 Census was 965,835 , consisting of 186,247 households. The average household size was 4.9 , similar to the nationwide average. The province had the second highest population density (276 persons $/ \mathrm{km}^{2}$ ) after Kandal Province (364 persons $/ \mathrm{km}^{2}$ ). In $2008,47 \%$ of the Takeo population was aged less than 20 years and $5 \%$ was aged over 60 years, reflecting the youthfulness of the population in Cambodia as a whole (Fig. 11.3). The population pyramid showed a bulge in the 10-19 years age cohort, reflecting the rapid population growth in the 1980s and the slowing of this growth since the mid-1990s. The bulge indicates a high population momentum, despite a declining birth rate, as well as increased numbers of young people seeking employment in what is already a densely populated province, putting pressure on landholdings and spurring outmigration.

The most important source of livelihood in the province remains agriculture, with $92 \%$ of households recorded as rice-producers in 2010 . WS rice accounts for $67 \%$ of arable land in the province and DS rice for $39 \%$ (mostly land that is not available for WS cultivation due to flooding). Only $4 \%$ of arable land is used for non-rice crops, including maize, soybean, mung bean, peanut, cassava, sweet potato, sesame, and vegetables, grown 


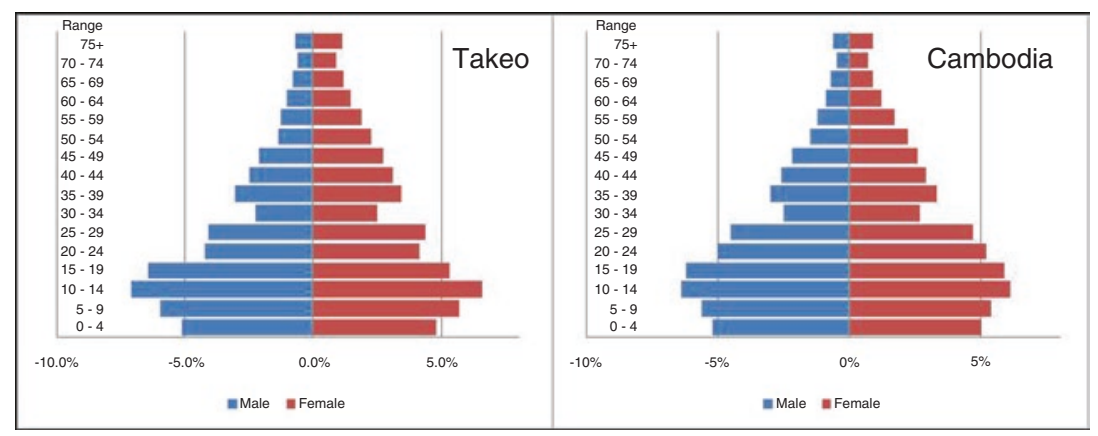

Fig. 11.3 Population pyramid for Takeo and Cambodia. (Source: Cambodian Census 2008)

mainly in Prey Kabbas District. Takeo is also a major producer of livestock, including cattle, pigs, and poultry. Surplus livestock is marketed to Phnom Penh or exported to Vietnam. Currently, the province has the smallest average farm size in the country; about $57 \%$ of households have less than 1 ha of paddy land and 5\% have no paddy land. Even so, average farm size increased from 0.63 ha in 2008 to 0.85 ha in 2012 (World Bank 2015), reflecting permanent outmigration to frontier zones and to Phnom Penh. In addition, around $9 \%$ of the resident population aged between 18 and 60 years migrates periodically to seek non-farm employment, mainly as factory and construction workers in the vicinity of Phnom Penh. The incidence of non-farm employment is unevenly distributed among the ten districts, ranging from 4\% to $16 \%$ (NCDD 2010).

Takeo was the third largest WS rice-producing province in Cambodia in 2012, accounting for $8 \%(198,768$ ha) of the area under WS rice cultivation nationally and producing $681,184 \mathrm{t}$ (nearly $10 \%$ of national production) (MAFF 2013). Though Takeo is relatively close to Phnom Penh, the area committed to rice cultivation has not been affected by the rapid growth of light industry in the vicinity of the capital. In fact, the area of WS rice had increased by $26 \%$ from 2008 to 2012. Almost all WS rice cultivation in Takeo is rainfed, with only a small area having access to supplementary irrigation to cope with droughts. Of this small irrigated area, $62 \%$ is irrigated from dams, $33 \%$ from natural sources of surface water, less than $5 \%$ from groundwater, and less than $1 \%$ from farm ponds. These sources of water are mostly unavailable during the DS, limiting opportunities for double cropping of rice. 
Nevertheless, Takeo Province is the largest producer of DS rice in Cambodia, producing 466,010 t from 96,507 ha in 2012 (MAFF 2013). The area under DS rice in 2012 represented a $21 \%$ increase from 2008. The proportion of farm households with access to DS irrigation varies from 11\% in Tram Kak District in the west to 64\% in Borei Chulsa District in the floodplain area to the east. The opportunity for DS rice cultivation and the expansion of the DS rice area have been influenced by a number of factors. Areas close to the Bassac River that are subject to regular flooding in the WS are increasingly being used for growing high-yielding varieties in the form of DS recession rice. The development of dams and canals to manage the floodwaters is providing favourable conditions for irrigating these DS rice crops. The expansion of cross-border trade with Vietnam has also provided an incentive for DS rice cultivation in the province. Apart from being a source of inputs and providing a ready market, this crossborder channel means the harvested paddy rice can be conveniently transported by road to mills in Vietnam immediately after harvest.

Although Takeo is a major rice-producing province, rice cultivation is still heavily reliant on traditional practices - draught animal power, manual labour, and conventional tools. The total number of draught animals recorded in 2012 was 373,800 head (mainly cattle), a $12 \%$ increase from 2008 (MAFF 2013; NCDD 2010). The average number of large ruminants per cattle-raising household ranged from 2.1 to 2.6 head between districts. Despite the large number of draught cattle, mechanisation of land preparation is increasing, either as a result of individual household investment or through contract operations. Nearly 8500 power tillers, accounting for $5 \%$ of rice farmers, were registered in Takeo Province in 2012 (MAFF 2013). The number of threshing contractors has also increased in recent years-in 2012 there were 1300 threshers registered, an increase of 400 over 2011 (MAFF 2013).

More significant has been the increasing use of combine harvesters, especially in the DS. There were 3743 small combine harvesters in the province in 2012, accounting for almost $50 \%$ of the national total. This represented a fourfold increase over the number in 2011. Large-capacity harvesters did not become available until 2012, with 91 machines being reported (MAFF 2013). Despite the rapid increase, the number of combine harvesters is not sufficient to harvest the entire rice crop in the province. In addition to the farmers' financial constraints, field conditions and the characteristics of WS rice varieties are not always suited to mechanical harvesting. 
Takeo Province has a large number of rice mills. Nevertheless, while there has been an increase in the level of mechanisation of farming operations, the number of small rice mills declined from 3800 in 2011 to 3500 in 2012 . There was also a decline in the number of large rice mills from ten in 2011 to six in 2012 (MAFF 2013). As noted, much of the DS rice harvest is transported directly to more efficient mills in Vietnam which incorporate large-scale driers, capable of handling paddy that has been transported directly from the farm without the usual sun-drying.

Despite the widespread use of traditional practices, there has been sufficient adoption of modern seed-fertiliser technology (and improved water management in the DS) to see a steady increase in yields and output (MAFF 2013). The average WS yield increased from $2.9 \mathrm{t} / \mathrm{ha}$ in 2007 to $3.4 \mathrm{t} / \mathrm{ha}$ in 2012 , and the average DS yield increased from $4.2 \mathrm{t} / \mathrm{ha}$ to $4.8 \mathrm{t} / \mathrm{ha}$ over the same period. These yield increases, combined with the expansion in cultivated area in both seasons mentioned above, has meant that WS production increased 35\%, and DS production 52\%, from 2007 to 2012 . Thus total rice production in 2012 was 1.2 million $t-59 \%$ from the WS harvest and $41 \%$ from the DS harvest. This represented $13 \%$ of national output. The estimated surplus for Takeo in 2012 was about 800,000 t, worth around USD 160 million, ${ }^{8}$ representing about $17 \%$ of the national surplus. Most of the surplus produced in Takeo was exported as paddy, either legally or illegally, to Vietnam.

\section{ConClusion}

Cambodia has a long history and comparative advantage in rice production. With relative political stability and access to improved varieties and other inputs, farmers have been able to increase the area cultivated and especially per-hectare yields so that total production has grown at over $5 \%$ since 1990. From being a rice-deficit country in the 1980s, the country has achieved self-sufficiency and, since 2010, become a serious exporter of paddy and milled rice. Rice farmers in Takeo Province have long made an important contribution to Cambodia's rice production and currently contribute $8 \%$ of WS output and $19 \%$ of DS output, as well as a major share of exports. The next chapters consider different dimensions of the rice value chain in Takeo to provide insights into the constraints and opportunities facing industry actors in that province and the potential for policy interventions. 


\section{Notes}

1. Data from UN Department of Economic and Social Affairs, Population Division, as analysed by Worldometers, http://www.worldometers.info/ world-population/cambodia-population/ (viewed 13 June 2017).

2. The 2010 Policy Paper also set a target of producing a paddy surplus of 4 million $\mathrm{t}$ by 2015 .

3. In $2013,1.7$ million $t$ of paddy were exported to Vietnam and 250,000 $t$ of paddy and 450,000 t of milled rice were exported to Thailand (ADB 2014).

4. Formal exports of rice increased from $1500 \mathrm{t}$ in 2008 to $378,850 \mathrm{t}$ in 2013. Informal exports of paddy (in milled equivalent) increased from 100,000 t to 1.54 million $\mathrm{t}$ (ADB 2014).

5. In 2011 , there were 28,474 small rice mills scattered throughout the ricegrowing areas.

6. The daily wage for labour hired in rice production in 2013 was USD 4.50 (World Bank 2015).

7. The southern part of Kampong Speu Province comprises part of the lowland plains region, while the northern part lies within the plateau and mountains zone.

8. A paddy price of KHR $800 / \mathrm{kg}$ or USD $200 /$ ton has been used to estimate the value of the paddy surplus.

\section{REFERENCES}

$\mathrm{ADB}, 2014$. Improving Rice Production and Commercialization in Cambodia: Findings from the Farm Investment Climate Assessment. Metro Manila: Asian Development Bank.

Delvert, J., 1961. Le Paysan Cambogien, translated by Sonal Shah. Paris: Mouton and Co.

Helmers, K., 1997. Rice in the Cambodian economy: past and present. In H. J. Nesbitt, ed., Rice Production in Cambodia, pp. 1-14. Manila: International Rice Research Institute.

Higham, C., 2014. Early Mainland Southeast Asia: From First Humans to Angkor. Bangkok: River Books.

Himmel, B. J., 2007. Khmer Rouge irrigation development in Cambodia. Unpublished manuscript.

Javier, E. L., 1997. Rice ecosystems and varieties. In H. J. Nesbitt, ed., Rice Production in Cambodia, pp. 39-81. Manila: International Rice Research Institute.

Johnston, R., Roberts, M., Thuon Try, and De Silva, S., 2013. Groundwater for Irrigation in Cambodia. Colombo: International Water Management Institute. 
Kiernan, B., and Boua, C., 1981. Peasants and Politics in Kampuchea, 1942-1981. London: Zed Books.

MAFF, 2013. Bulletin of Agricultural Statistics and Studies. Phnom Penh: Department of Planning and Statistics, Ministry of Agriculture, Forestry and Fisheries.

MRC, 2017. Physiography of the Mekong Basin, Mekong River Commission. Available at http://www.mrcmekong.org/mekong-basin/physiography/ (viewed 8 June 2017).

NCDD, 2010. Provincial Database. Phnom Penh: National Committee for Subnational Democratic Development.

Nesbitt, H. J., 1997a. Topography, climate, and rice production. In H. J. Nesbitt, ed., Rice Production in Cambodia, pp. 16-19. Manila: International Rice Research Institute.

Nesbitt, H. J., 1997b. Constraints to rice production and strategies for improvement. In H. J. Nesbitt, ed., Rice Production in Cambodia, pp. 108-122. Manila: International Rice Research Institute.

NIS, 2008. National Census in 2008. Phnom Penh: National Institute of Statistics, Ministry of Planning, Cambodia.

RGC, 2010. Policy Document on Promotion of Paddy Rice Production and Export of Milled Rice. Phnom Penh: Royal Government of Cambodia.

Sakhan, S., Seang, L., Leng, L., and Then, R., 2007. Rice ecosystems and cultivation in Cambodia. In S. Men, ed., Rice Crop in Cambodia, pp. 134-155. Phnom Penh: Cambodian Agricultural Research and Development Institute.

Slocomb, M., 2010. An Economic History of Cambodia in the Twentieth Century. Singapore: NUS Press.

White, P. F., Oberthur, T., and Pheav, S., 1997. Soils Used for Rice Production in Cambodia: A Manual for their Recognition and Management. Manila: International Rice Research Institute.

World Bank, 2015. Cambodian Agriculture in Transition: Opportunities and Risks. Economic and Sector Work, Report No. 96308-KH. Washington, DC: World Bank.

World Bank, 2017. Cambodia Overview. Available at http://www.worldbank. org/en/country/cambodia/overview (viewed 5 June 2017). 
Open Access This chapter is licensed under the terms of the Creative Commons Attribution 4.0 International License (http://creativecommons.org/licenses/ by $/ 4.0 /$ ), which permits use, sharing, adaptation, distribution and reproduction in any medium or format, as long as you give appropriate credit to the original author(s) and the source, provide a link to the Creative Commons licence and indicate if changes were made.

The images or other third party material in this chapter are included in the chapter's Creative Commons licence, unless indicated otherwise in a credit line to the material. If material is not included in the chapter's Creative Commons licence and your intended use is not permitted by statutory regulation or exceeds the permitted use, you will need to obtain permission directly from the copyright holder.

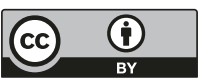

